\title{
Okul Dışı Öğrenme Ortamlarında Yürütülen Etkinliklerin Öğrencilerin Sosyobilimsel Konulara ilişskin Görüşlerine Etkisi: Organ Bağışı ve GDO'
}

\author{
Dr.Melike Yavuz Topaloğlu \\ MEB-Türkiye \\ meykeyavuz@hotmail.com
}

\author{
Doç.Dr.Fatime Balkan Kıyıcı \\ Sakarya Üniversitesi-Türkiye \\ fbalkan@sakarya.edu.tr
}

\begin{abstract}
Özet:
Bu araştırma ile; okul dışı öğrenme ortamlarında yürütülen etkinliklere bağlı olarak organ bağısıı ve GDO sosyobilimsel konularına ilişkin yedinci sınıf öğrencilerinin görüşlerinin belirlenmesi amaçlanmıştır. Bu betimsel çalışma 2014-2015 eğitim-öğretim döneminde bir ortaokulda öğrenim görmekte olan 21 yedinci sını öğrencisi ile yürütülmüş̧ür. Araştırma kapsamında diyaliz merkezine ve TÜBiTAK Marmara Araştırma Merkezine farklı iki ziyaret düzenlenmiştir. Araştırma verileri ziyaret öncesi ve sonrasında ön ve son test olarak uygulanan açık uçlu soru formları ile elde edilmiştir. Veriler içerik analiziyle analiz edilmiştir. Araştırma sonucunda öğrencilerin büyük çoğunluğunun araştırma merkezinde yapılan uygulama öncesinde ve sonrasında canlılar üzerinde yarattığı sağlık sorunları ve çeşitli zararlardan ve ürünlerin doğal halini kaybetmesinden dolayı GDO'ların zararlı olduğunu belirttiği sonucuna ulaşılmıştır. Ayrıca uygulama sonrasında GDO'ların yararlı olduğunu düşünen öğrenci sayısının dikkat çekici şekilde artığı gözlemlenmiştir. Diyaliz merkezine yapılan ziyaret öncesinde ve sonrasında öğrencilerin organ bağışının yapılmasına kaliteli yaşam imkanı sunma, hayat kurtarma, organ bekleyenlerin çoğalması gibi yaşamsal boyutlardan dolayı olumlu yönde baktığı belirlenmişstir.
\end{abstract}

Keywords: Genetiği değiştirilmiş organizmalar (GDO), organ bağışı, okul dışı öğrenme ortamları, sosyobilimsel konular, ögrenci görüşleri. 


\section{GiRiş}

Organ bağışı yapıp yapmama, genetiği değiştirilmiş organizmaların yararlı mı zararlı mı olduğuna karar verip tüketip tüketmemeyi tercih etme durumları ülkemizde sıklıkla tartışılan iki önemli konu başlığıdır. Hastaların hayatını kurtarmak, yaşam kalitesi ve süresini artırmak amacıyla yapılan organ bağışı ve organ nakli konusu; dini inançlar, organ alınması ve nakline karşı olumsuz tutumlara sahip olma, düzgün işleyen bir sürecin takip edilmediği, yoksul insanların bu sürece dahil olamadığı, alkol sorununa bağlı olarak yaşanan organ yetmezliğinin diğer organ ihtiyacı olan hastalarla aynı olmadığı düşüncesi gibi boyutların insanlar arasında sürekli tartışılmasından dolayı sosyobilimsel bir konu olma özelliği taşımaktadır (Saylan, 2014). Benzer şekilde canlı varlıkların özelliklerini değiştirmek veya onlara yeni özellikler kazandırmak amacıyla gen dizilimleriyle oynanarak yapılan genetiği değiştirilmiş organizmalar da; ilerleyen yıllarda sağlık, çevre ve gıdalar üzerinde çeşitli olumsuz etkiler yaratabilecek, bu görüşe zıt olarak artan dünya nüfusu için gerekli ilaç ve besin ihtiyacını karşılayabilecek olma durumlarına bağlı olarak sosyobilimsel bir konu olma doğasına sahiptir (Kılınç, Kartal, Eroğlu, Demiral, Afacan, Polat ve Görgülü, 2013). Çünkü sosyobilimsel konular; yerel, ulusal ve uluslararası düzeyde başta bilim insanları olmak üzere toplumda yer alan bireyler arasında görüş ayrılıklarının olduğu ve bireylerin karar vermede zorlandığı, risk ve fayda analizlerinin yürütüldüğü sosyal boyutları olan bilimsel içerikli meselelerdir (Ratcliffe ve Grace, 2003). Bu bakımından organ bağışı-nakli ve GDO'nun bireylerin karar vermede zorlandığı, etik sorgulamaları gerektiren tartışmalı, sosyal ve bilimsel boyutları olan konular olduğu ifade edilebilir.

Bu ve bunun gibi diğer sosyobilimsel konular bilim, teknoloji ve fenin sürekli ilerleyişine bağlı olarak günlük yaşamımızda etkisini fazlaca göstermektedir. Dolayısıyla sosyobilimsel konularda alınacak kararların toplumundaki çağdaş yaşamın hatta dünyamızın geleceğinin şekillenmesine katkı sağlayabileceği ifade edilebilir. Bu sebepten fen eğitimi kapsamında yetiştirilmesi hedeflenen fen okuryazarı bireylerin günlük hayatta karşılaştıkları sosyobilimsel konular ile ilgili kendi fikir ve düşüncelerini ifade edebilecek yeterlilikte bilgi sahibi olması (Kolstø vd., 2006; Sadler, 2004) ve bu bilgiler ışığında tartışmalar yürüterek konuyla ilgili kendi kararını veya hükmünü verebilecek nitelikte olması gerekmektedir (Sadler ve Zeidler, 2005). Oysaki yerli literatürde yapılan çalışmalar toplumun çeşitli kesimlerinde yer alan bireylerin organ bağışı-nakli (Bölükbaş, Eyüpoğlu ve Kurt, 2004; Akış, Katırcı, Uludağ, Küçükkılıç, Gürbüz, Türker, Kayacan, Öngel ve Gül, 2008; Çetin, Turgut ve Kaçar, 2014; Doğan, Toprak, Sunal ve Doğan, 2012; Koçak, Aktaş, Şenol, Kaya ve Bilgin 2010) ve GDO ile ilgili (Ergin vd., 2008; Demirci, 2008; Bici, 2010; Özdemir, Güneş ve Demir, 2010; Demir ve Düzleyen, 2012) bilgilerinin yeterli düzeyde olmadığını vurgulamıştır.

Bireylerin bilgi birikimini artırmak ve toplumdaki fen okuryazarı düzeyini artırmak için birçok eğitimci fen öğretim programına sosyobilimsel konuların dahil edilmesi gerektiğini vurgulamıştır (Driver, Newton ve Osborne, 2000; Sadler, 2004; Zeidler ve Keefer, 2003; Zeidler ve Sadler, 2008). Bu şekilde fen eğitiminde sosyobilimsel konulara yer verilmesiyle toplumu ilgilendiren bilimsel konularla ilgili fen okuryazarı bir bireyin taşıması gereken bilimsel düşünme, karar verme ve yargıda bulunma, problem çözme, tartışma ve sorgulama becerilerinin geliştirilmesi (Nuangchalerm, 2010; Sadler ve Zeidler, 2004) ve öğrencilerin fenin hayatla olan ilişkisinin farkına vararak fen ve toplum arasındaki etkileşimi ahlaki ve etik çerçevede değerlendirebilme imkanı elde edebilmeleri amaçlanmıştır (Sadler ve Zeidler, 2004). Bu bilgiler ışığında fen derslerinde sosyobilimsel konuların ele alınmasının hem öğrencinin kendi kişisel gelişimi için hem de toplumun gelişip ilerleyebilmesi için oldukça önemli bir araç olduğu vurgulanabilir.

Eğitim öğretim faaliyetleri kapsamında öğrencilerin hayatın içindeki tartışmalı, basit sonuçları olmayan karmaşık sosyobilimsel konuları etkili bir şekilde anlayıp yorumlayabilmeleri için sınıf içi etkinliklerin yanında okul dışı öğrenme ortamları da bir araç olarak kullanılabilir 
(Yavuz Topaloğlu ve Balkan Kıyıcı, 2017). Okul dışı öğrenme ortamlarında sosyobilimsel konulara yer verilmesiyle; günlük yaşam içerisindeki fikir birliğine varılmayan tartışmalı sosyal sorunların kendi doğal ortamında incelenebilmesi mümkün olabilir. Bu şekilde öğrenciler sosyobilimsel konular ile ilgili kendi öğrenmelerini ve bilgi dünyasını yapılandırabilir. Çünkü okul dışı öğrenme ortamları ile, bireylere sınıf içerisinde sunulması güç olan ilk elden gözlem yapma ve deneyim kazanma fırsatı (Emmons, 1997; Rivkin, 2000) ve fen konularılya ilgili kavram ve nesnelerle etkileşimde bulunma ve merak duygusu uyandırma imkanı sunularak tam ve anlamlı öğrenmelerin gerçekleştirilmesi sağlanmaktadır (Ramey-Gassert, 1997). Bu şekilde öğrencinin kendi için uygun öğrenme stillini belirleyerek kendi hızında öğrenmeler gerçekleştirmesi sağlanmaktadır (Melber ve Abraham, 1999). Bu bağlamda öğrencinin bizzat kendisi sürece dahil olup tartışmalı ve karmaşık olan sorun ile ilgili kararını okul dışı öğrenme ortamlarında edindiği öğrenmelere bağlı olarak verebilir.

Okul dışı öğrenme ortamları kullanılarak fen eğitiminde formal eğitim ile gerçekleştirilmesi ve vurgulanması zor olan birçok konu ve kavramın öğrenciye kolaylıkla öğretilebileceği göz önünde bulundurulduğunda organ bağışı-nakli ve GDO sosyobilimsel konularının Devlet Hastanesi diyaliz merkezine ve TÜBITAK Marmara araştırma merkezine yapılan ziyaretler kapsamında işlenerek öğrencilerin bu konulara bakış açılarının ele alınmasının alana katkı sağlayacağı düşünülmüştür. Ayrıca literatürde son yıllarda küçük yaş grubuyla okul dışı öğrenme ortamında yürütülen çalışmaların çoğunluğunun sosyobilimsel konulardan farklı konular dahilinde yürütüldüğü belirlenmiştir (Armağan, 2015; Akça, 2016; Sontay, Tutar ve Karamustafaoğlu, 2016; Şahin ve Yazgan, 2013; Yanmaz, 2017). Ayrıca organ bağışı- nakli ve GDO konuları insan yaşamına olan etkileri bakımından toplumdaki bireylerin yeterince bilinçlendirilmesi anlamında üzerine eğilinmesi gereken ciddi konulardır. Bu kapsamda özellikle çocukların bu konulara ilişkin bilgi düzeyleri ve düşünceleri oldukça önemlidir. Çünkü gelecekte Dünya'nın düzenine ve gelişimine yön verecek olan kişiler çocuklardır. Oysaki literatürde ortaokul öğrencilerinin organ bağışı-nakli ve GDO sosyobilimsel konularına yönelik bilgilerini ve görüşlerini inceleyen sınırlı sayıda çalışmaya rastlanmıştır (Demir ve Düzleyen, 2012; Bilen ve Özel, 2012; Bakioğlu ve Karamustaoğlu, 2014). Bu bakımdan böyle önemli sosyal sorunlar ile ilgili çocukların katılımcı olduğu birtakım çalışmaların yürütülmesi ileride alınabilecek toplumsal kararların daha sağlıklı olabilmesinde oldukça değerlidir. Bu anlamda bu çalışmanın önemli olduğu düşünülmektedir. Ek olarak hem sosyobilimsel konular hem de okul dışı öğrenme ortamları; öğrencilerin, fen bilimleri öğretim programının temelinde benimsenen araştırmasorgulamaya dayalı öğrenme stratejisinin esas aldığı şekilde öğrencinin bilgilerini, karşılaştığı olguları ve durumları sorgulamasına ve araştırmasına imkan tanıyarak öğrenmeler gerçekleştirmelerine fırsat sunmaktadır. Buna bağlı olarak; okul dışı öğrenme ortamlarının ve sosyobilimsel konuların fen bilimleri konularıyla ilişkilendirilerek okullarda nasıl ele alınabileceği hakkında örnek teşkil etmesi açısından değerli olduğu vurgulanabilir. Bu sebeplere bu çalışma ile; okul dışı öğrenme ortamlarında yürütülen etkinliklere bağlı olarak organ bağışı ve GDO sosyobilimsel konularına ilişkin yedinci sınıf öğrencilerinin görüşlerinin belirlenmesi amaçlanmıştır.

\section{YÖNTEM}

Araştırma, okul dışı öğrenme ortamlarında yürütülen etkinliklere bağlı olarak organ bağışı ve GDO sosyobilimsel konularına ilişkin yedinci sınıf öğrencilerinin açık uçlu soru formları ile görüşlerinin ortaya konduğu betimsel bir çalışmadır. Betimsel çalışmalar ile çalışılan olguya dair bireylerin tutum, görüş veya davranışlarının ortaya çıkarılması amaçlanmaktadır (Creswell, 2008).

\section{Çalışma Grubu}

Bu araştırmada katılımcılar amaçı örnekleme yöntemlerinden ölçüt örnekleme yöntemi ile belirlenmiştir. Ölçüt örnekleme, araştırılan durumun derinlemesine incelenebilmesi için önceden 
planlanan ölçütleri kapsayan örnek olay türlerinin seçilmesi ve kullanılmasıdır (Ary ve diğ., 2010). Bu araştırmadaki katılımcılar Sakarya Ili'nin Hendek İlçesi'nde bulunan bir ortaokulda 2014-2015 eğitim-öğretim yılında öğrenim görmekte olan 21 yedinci sınıf öğrencisinden oluşmaktadır.

Araştırmada öğrencilerin daha önceden belirlenmiş sosyobilimsel konulara uygun olarak okul dışı öğrenme ortamlarına götürülmesi hedeflendiğinden dolayı bu hedefin gerçekleştirilmesine olanak sağlayan bir okul seçilmiştir. Ayrıca 2005 Fen ve Teknoloji ve 2013 Fen Bilimleri öğretim programına göre bu çalışma kapsamında okul dışı öğrenme ortamlarında yürütülecek sosyobilimsel konuların 7. ve 8. sınıf fen konu ve ünitelerinde yer aldığı ancak 8. sınıf öğrencilerinin liselere giriş sınavına hazırlandıkları göz önünde bulundurulduğunda çalışmanın 7 . sınıf öğrencileri ile birlikte yürütülmesine karar verilmiştir. Bu araştırmada öğrenciler aşağıda belirlenen ölçütler kapsamında seçilmiştir:

- 7. sınıf öğrencisi olması,

- okul dışı öğrenme ortamlarında düzenlecek etkinliklere katılabiliyor olması

- sosyobilimsel ve okul dışı öğrenme ortamları ile ilgili temel bilgi ve ilgiye sahip olmasıdır.

Belirlenen bu ölçütler çerçevesinde Çalışma grubunda yer alacak öğrencileri seçebilmek için bu ortaokulda bulunan 169 7.sınıf öğrencisine okul dışı öğrenme ortamları ve sosyobilimsel konulara dair iki sorunun, öğrencilerin gönüllülük durumunu belirlemek için ise bir sorunun yer aldığı bir form uygulanmıştır. Bu formdan elde edilen veriler kapsamında sorulara uygun yanıt veren ve gönüllü olan 47 öğrenci seçilmiştir. Daha sonra bu seçilen öğrenciler arasından ailelerinin okul dışı öğrenme ortamlarında yürütülecek gezilere izin verme durumu ve okuldaki öğretmenlerinin öğrenci profili hakkındaki tutumu göz önüne alınarak çalışma grubunda yer alacak 21 kişi belirlenmiştir.

\section{Tablo 1}

Araştırmanın Çalışma Grubunda Yer Alan Öğrencilerin Demografik Özellikleri

\begin{tabular}{llll}
\hline Değişken & Öğrenciler & (f) & (\%) \\
\hline \multirow{3}{*}{ Cinsiyet } & Kız & 11 & 52.38 \\
& Erkek & 10 & 47.62 \\
& Toplam & 21 & 100 \\
\hline \multirow{3}{*}{ Anne Eğitimi } & Illkokul & 9 & 42.86 \\
& Ortaokul & 3 & 14.28 \\
& Lise & 6 & 28.57 \\
& Üniversite & 3 & 14.28 \\
& Toplam & 21 & 100 \\
\hline \multirow{3}{*}{ Baba Eğitimi } & Ilkokul & 2 & 9.52 \\
& Ortaokul & 4 & 19.05 \\
& Lise & 7 & 33.33 \\
& Yüksekokul & 1 & 4.76 \\
& Üniversite & 6 & 28.57 \\
& Lisansüstü & 1 & 4.76 \\
& Toplam & 21 & 100 \\
\hline
\end{tabular}

\section{Veri Toplama}

Bu araştırmada veri toplama aracı olarak iki adet açık uçlu soru formu kullanılmıştır. Açık uçlu sorular; bireylerin deneyim, fikir ve duygularını tanımlarken kullandıkları tema, imge ve kelimeleri inceleme fırsatı sunması açısından oldukça önemlidir (Patton, 2014). Tablo 2'de Fen bilimleri dersi öğretim programına uygun kazanımlar kapsamında hazırlanan organ bağışı ile ilgili olan açık uçlu soru formu Devlet Hastanesi diyaliz merkezinde yürütülen ziyaret ve etkinlikler öncesinde ve sonrasında, GDO ile ilgili olanı ise TÜBITAK Gebze Marmara Araştırma Merkezinde yürütülen ziyaret ve etkinlikler öncesinde ve sonrasında olmak üzere ön ve son test olarak iki kez uygulanmıştır. Araştırmada kullanılan açık uçlu soru formlarında organ bağışının yapılıp yapılamaması ve genetiği değiştirilmiş organizmaların yararlı ya da zararlı olmasına ilişkin öğrencilerin kararlarının ve bu kararlarının nedenlerinin tespit edilmesi amaçlanmıştır. 
Araştırma kapsamında öğrencilere aşağıdaki sorular yöneltilmiştir:

- Organ bağısıının yapılması ya da yapılmaması ile ilgili düşüncelerin nelerdir? Bu konuda senin kararın nedir? Bu konuyla ilgili düşüncelerinizi ayrıntılı olarak nedenleriyle birlikte belirtiniz.

- Sence genetiği değiştirilmiş organizmalar yararlı mı zararlı mı? Bu konuda senin kararın nedir? Bu konuyla ilgili düşüncelerinizi ayrıntılı olarak nedenleriyle birlikte belirtiniz.

Tablo 2

Araştırma Kapsamında Temel Alınan Kazanımlar

\begin{tabular}{|c|c|c|c|c|}
\hline Ünite & Hafta & Öğretim Programında Yer Alan Kazanımlar & $\begin{array}{l}\text { Sosyo } \\
\text { Bilimsel } \\
\text { Konular }\end{array}$ & $\begin{array}{l}\text { Okul Dışı } \\
\text { Öğrenme } \\
\text { Ortamı }\end{array}$ \\
\hline 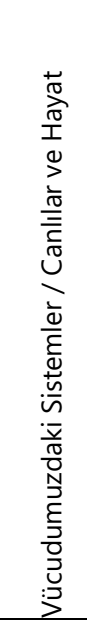 & 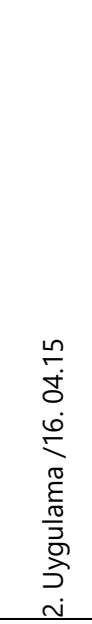 & $\begin{array}{l}\text { 2013 Fen Bilimleri Programı kazanımı } \\
\text { 7.1.5. Organ Bağışı ve Organ Nakli } \\
\text { 7.1.5.1. Organ bağışı ve organ naklinin toplumsal dayanışma } \\
\text { açısından önemini kavrar. } \\
\text { 2005 Fen ve Teknoloji Programı kazanım (7.sınıf): } \\
\text { 5.3. Organ bağışının önemini vurgular. } \\
\text { Poster Hazırlama:Öğrenciler gruplara ayrılır. Her grup organ nakline } \\
\text { yönlendirici birer slogan, poster veya drama etkinliği hazırlar ve sınıfa } \\
\text { sunar. En ilgi çekici slogan ve poster seçilerek okul panosunda } \\
\text { sergilenir (5.3), (BSB-25, 27, 32). } \\
\text { Genç Gazeteci: Öğrenciler organ nakli yapılmış bir kişi ile röportaj } \\
\text { yapar ve bunu sınıfa sunar. Organ naklinin önemi tartışılır (5.3), (BSB- } \\
\text { 25, 27, 32). }\end{array}$ & 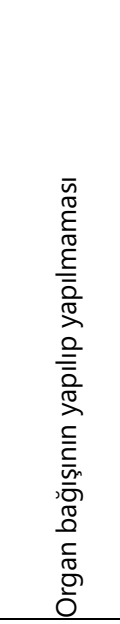 & 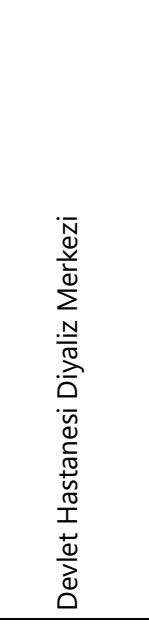 \\
\hline 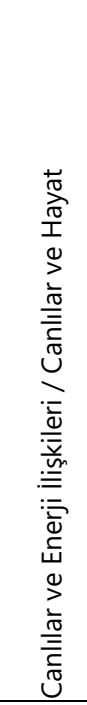 & 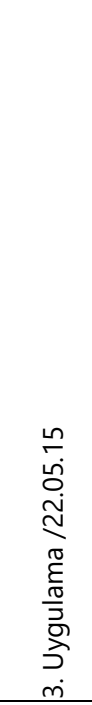 & $\begin{array}{l}\text { 8.5.4. Biyo-teknoloji } \\
\text { 8.5.4.1. Günümüzdeki biyo-teknoloji uygulamalarının olumlu ve } \\
\text { olumsuz etkilerini, araştırma verilerini kullanarak tartışır. } \\
\text { Eski kazanım (8. Sınıf): } \\
\text { 4.9. Biyoteknolojik çalışmaların hayatımızdaki önemi ile ilgili bilgi } \\
\text { toplayarak çalışma alanlarına örnekler verir (FTTÇ- } \\
\text { 16,17). } \\
\text { Münazara: Sınıfta altışar kişilik iki grup oluşturulur. Birinci grup } \\
\text { genetik mühendisliği ve biyoteknoloji uygulamalarının olumlu, ikinci } \\
\text { grup ise olumsuz yönleri ile ilgili bilgi toplar. Bu iki grup, öğretmen } \\
\text { rehberliğinde sınıfta tartışır. Sınıftaki diğer öğrenciler grupların ortaya } \\
\text { koydukları görüşlerden yola çıkarak genetik mühendisliği ve } \\
\text { biyoteknoloji uygulamalarına ilişkin görüslerini yazarlar. Ayrıca bu } \\
\text { öğrenciler grup değerlendirme formları kullanarak tartışan grupların } \\
\text { performanslarını değerlendirirler } \\
\text { (4.7), (BSB-25, 27, 32). }\end{array}$ & 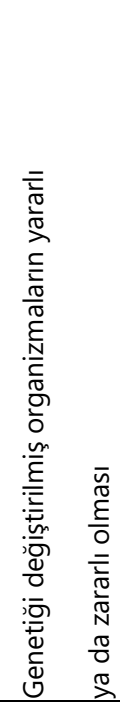 & 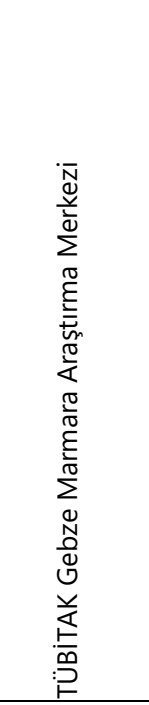 \\
\hline
\end{tabular}

\section{Veri Analizi}

Organ bağışı ve GDO konusuna yönelik açık uçlu soru formlarından elde edilen verilerin analizinde içerik analizine başvurulmuştur. İçerik analizi ile; veri toplama araçlarından elde edilen veriler öncelikle düzenlenir daha sonra bu düzenlenen verilerden kod listeleri oluşturulur ve ortaya çıkan bu kodlar belirli kategoriler altında temalaştırılır (Miles ve Huberman, 1994). Dolayısıyla bu çalışmada ilk olarak açık uçlu soru formlarından elde edilen öğrencilerin ifadeleri incelenmiş ve düzenlenmiş, daha sonra öğrenci ifadelerinden çıkarılan kod ve kodlara bağlı temaların frekans ve yüzde hesaplamalarının yer aldığı tablolar oluşturulmuştur. Miles ve Huberman'ın (1994) ifade ettiği görüş birliği ve görüş ayrılığına dayalı formül ile farklı araştırmacılardan elde edilen kodların tutarlılığı belirlenmiştir. Bu bağlamda açı uçlu soru 
formlarından elde edilen ön ve son verilerin toplam analizlerinin değerlendirme uyum yüzdesi \%77 olarak bulunmuştur. Yıldırım ve Şimşek'e (2011) ve Miles ve Huberman (1994) na göre; yapılan hesaplamalar sonucunda iki araştırmacı arasında olan değerlendirme uyum yüzdesinin en az \%70 oranında olması analiz sürecinin güvenilir olduğunu göstermektedir. Bu nedenle bu çalışmadaki nitel veri analizinin güvenilir olduğu vurgulanabilir.

\section{Geçerlik ve Güvenirlik}

Bu çalışmada inandırıcııı̆ını (iç geçerliğini) artırmak için veri toplama araçlarından elde edilen veriler araştırmacı dışında farkı bir araştırmacı tarafından analiz edilerek araştırmacı çeşitlemesi ve uzman incelemesi de sağlanmıştır. Aynı zamanda araştırmacının katılımcılar ile uzun süreli etkileşim içerisine girmesi inandırıcılığı artıran bir başka göstergedir (Yıldırım ve Şimşek, 2011). Araştırmanın aktarılabilirliğini (dış geçerliğini) sağlamak için; araştırmanın modeli, katılımcıların özelliklerinin betimlenmesi, kullanılan veri toplama aracı, verilerin toplanma süreleri, uygulamayı nasıl gerçekleştirdiği yöntem kısmında ayrıntılı ve zengin bir biçimde sunulmuştur. Aynı zamanda araştırma kapsamında amaçlı örnekleme yöntemlerinden birinin kullanılması da aktarılabilirliğini artıran bir başka göstergedir (Yıldırım ve Şimşek, 2011). Araştırmanın tutarlılığını (iç güvenirliğini) sağlamak için; araştırmada kullanılan ve öğrencilerin veri toplama araçlarına verdiği yanıtlardan alıntılar eklenmiştir. Bunun yanında bu araştırmanın teyit edilebilirliği (dış güvenirliğini) sağlamak için; veri toplama aracının nasıl uygulandığı ve verilerin nasıl analiz edildiği detaylarıyla açıklamıştır.

\section{Uygulama Süreci}

Araştırmanın uygulama öncesi, uygulama ve uygulama sonrası süreci Şekil 1'de ayrıntılı olarak sunulmuştur.

Uygulama kapsamında öğrencilerin organ bağışı ve GDO sosyobilimsel konuları ile ilgili konu ve kavramları doğal ortamında gözlemleyerek değerlendirmeleri ve birinci elden bilgi almaları amacıyla okul dışı öğrenme ortamlarına Devlet Hastanesi diyaliz merkezine ve TÜBITAK Gebze Marmara Araştırma Merkezine) ziyaretler gerçekleştirilmiştir. Yürütülen bu ziyaretler öncesinde; literatür taraması yapılmış araştırma kapsamında yer alan sosyobilimsel konular seçilmiştir. Daha sonra belirlenen sosyobilimsel konular ile ilgili öğretim programında yer alan kazanımlar belirlenmiş ve konuyla ilgili olan okul dışı öğrenme ortamında yürütülecek olan ziyaretler (öğrenci ve yetkililer bilgilendirilmesi, öğrenciye aktarılacak olan içeriğin hazırlanması, gerekli izinlerin alınması gibi) planlanmıştır. Ziyaretlerin planlanmasının ardından araştırma kapsamında kullanılan veri toplama aracı ve dokümanlar uzman görüşleri çerçevesinde hazırlanmıştır. Devlet Hastanesi diyaliz merkezine yapılan ziyaret öncesinde hazırlanan "Organ bağışı Konusuna Yönelik Açık Uçlu Soru Formu", TÜBiTAK Gebze Marmara Araştırma Merkezine yapılan ziyaret öncesinde hazırlanan "GDO Konusuna Yönelik Açık Uçlu Soru Formu" katılımcılara ön test olarak uygulanmıştır. Devlet Hastanesi diyaliz merkezi ziyareti kapsamında; uzman kişi tarafından organ bağışı ve organ naklinin ne olduğuna, doku uyumunun ne zaman önemli olduğu, organ bağışı belgesinin ne işe yaradığı, hangi organların nakil olacağı, organ naklinin hangi durumlarda yapılacağı, organ bağışını kimlerin yapabileceği, organ bağışı ve naklinin olumlu yönleri, organ bağışı ve naklinin olumsuz yönleri, diyaliz merkezinin amacı ve orda yapılan çalışmalar hakkında bilgiler verilmiştir. Diyaliz merkezinde hastaların yer aldığı bölüm ve merkezin bazı halka açık kısımları gezdirilmiş ve makinaların nasıl çalıştığı, diyaliz hastalarının nasıl olduğu ve diyaliz hastalarına neler yapıldığı ile ilgili bilgiler elde edilmiştir.

TÜBITAK Gebze Marmara Araştırma Merkezi ziyareti kapsamında ise; uzman kişi tarafından GDO, biyoteknoloji, genetik mühendisliği ne olduğuna ve nasıl çalışmalar yaptığına, GDO'ların potansiyel riskleri ve faydaları ve TÜBITAK Gebze Marmara Araştırma Merkezinde yürütülen çalışmalar hakkında bilgilendirme yapılmıştır. Öğrenciler önce merkezde yer alan GDO'lu mısıların yetiştirildiği laboratuarları ve GDO'lu mısırları görmüştür. Daha sonra merkezin içinde izin verilen ölçüde bulunan kısımlar gezilmiş ve merkezde yürütülen çalışmalara dair bilgiler elde edilmiştir. Her bir okul dışı öğrenme ortamına yapılan ziyaret süresince katılımcılar 
kendilerine dağıtılan gez-gör-öğren kitapçı̆̆ını doldurmuş ve yetkililere merak ettikleri konular ile ilgili sorular sormuştur.

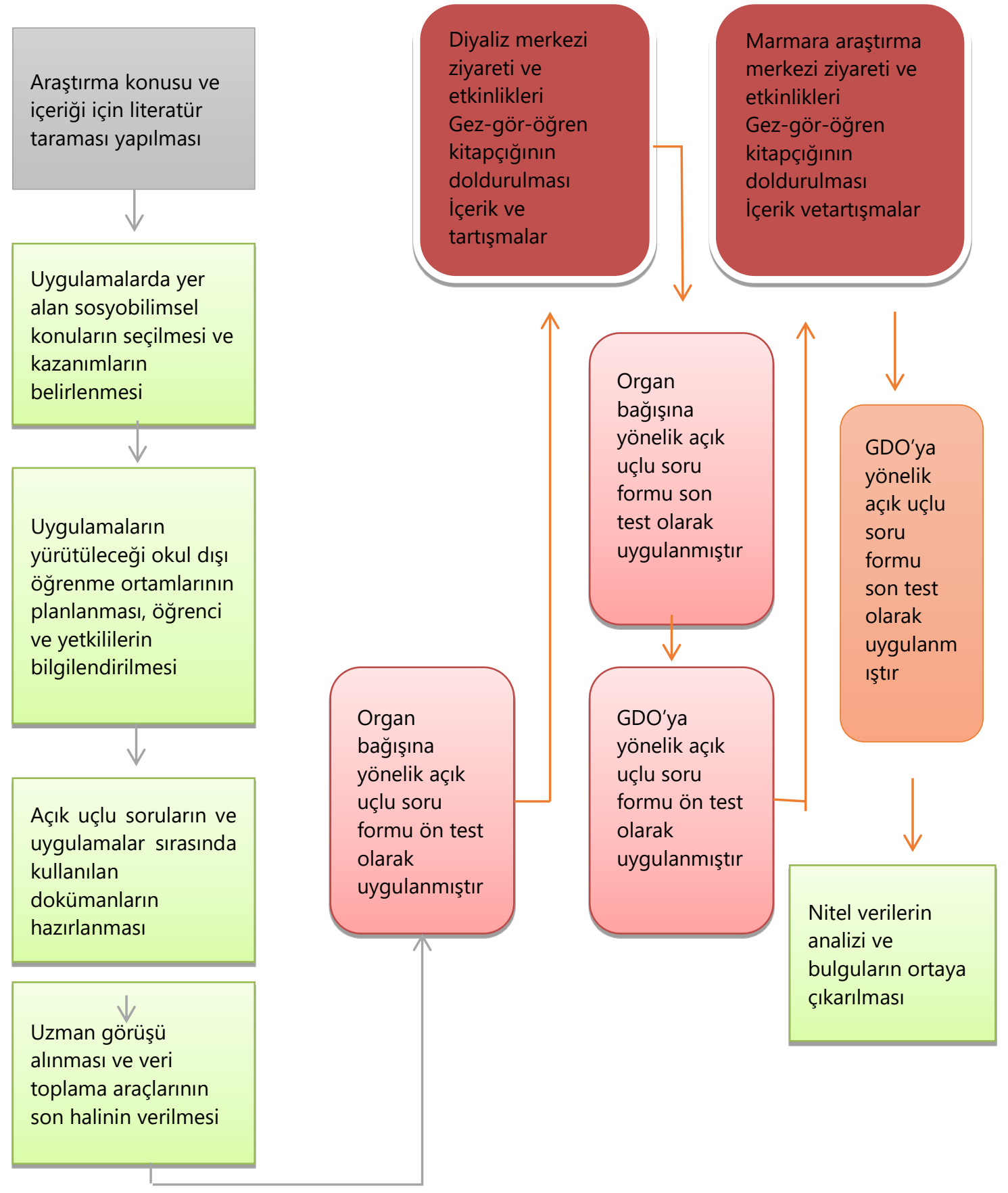

Şekil 1

Araştırmanın Uygulama Öncesi, Uygulama ve Uygulama Sonrası Süreci

Her biri ayrı birer gün içerisinde gerçekleştirilen her bir ziyaret sonrasında okulda verilen bir saatlik ihtiyaç molasının ardından öğrencilerle tekrar bir araya gelinmiş ve diyaliz ve araştırma merkezinde yürütülen uygulamaya ilişkin olarak konuyla ilgili görselleri içeren sunumlar yürütülerek ziyaretler sırasında edinilen bilgiler hakkında tartışmalar yapılmıştır. Her bir ziyaret sonrasında belirlenen farklı gün ve saatte 21 yedinci sınıf öğrencisine "Organ bağışı Konusuna Yönelik Açık Uçlu Soru Formu" ve "GDO Konusuna Yönelik Açık Uçlu Soru Formu" son test olarak uygulanmıştır. 


\section{BULGULAR}

Organ bağışına yönelik olan açık uçlu soru formunda yer alan ilk soru ile organ bağışı yapılıp yapılmaması ile ilgili kararları ve bu kararların nedenlerine ilişkin öğrencilerin görüşlerine Tablo 3 ve Tablo 4 'te yer verilmiştir.

\section{Tablo 3}

Organ Bağışının Yapılıp Yapılmamasına Ilişkin Öğrencilerin Düşünceleri

\begin{tabular}{|c|c|c|c|c|c|c|c|}
\hline Tema & Kodlar & Ön test & $f$ & $\%$ & Son test & f & $\%$ \\
\hline \multirow{4}{*}{ 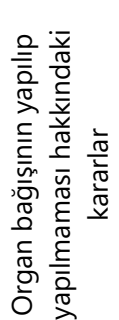 } & Yapılmalı & ö1,ö2,ö3,ö5,ö6,ö7,ö & 20 & 95.24 & ö1,ö2,ö3,ö4,ö5, & 21 & 100 \\
\hline & & 8,ö9,ö10,ö11,ö12,ö & & & ö6,ö7,ö8,ö9,ö10,ö11,ö1 & & \\
\hline & & 13,ö14,ö15,ö16,ö17， & & & 2,ö13,ö14,ö15,ö16,ö17, & & \\
\hline & Karasız & ö4 & 1 & 4.76 & & & \\
\hline & & Tüm öğrenciler & 21 & 100 & Tüm öğrenciler & 21 & 100 \\
\hline
\end{tabular}

Tablo 3'te organ bağışının yapılıp yapılmamasına ilişkin ön formda yer alan açık uçlu soruya öğrencilerin verdiği cevaplar incelendiğinde; \%95.24'ü, son formlarda ise\%100'ü organ bağışının "yapılması" gerektiği yönünde kararlarını bildirmiştir. Ön ve son formlardan elde edilen bu bulgular doğrultusunda; öğrencilerin organ bağışının yapılmasına olumlu yönde baktığı tespit edilmiştir.

\section{Tablo 4}

Organ Bağışının Yapılması ile ilgili Kararların Nedenlerine ilişskin Öğrencilerin Düşünceleri

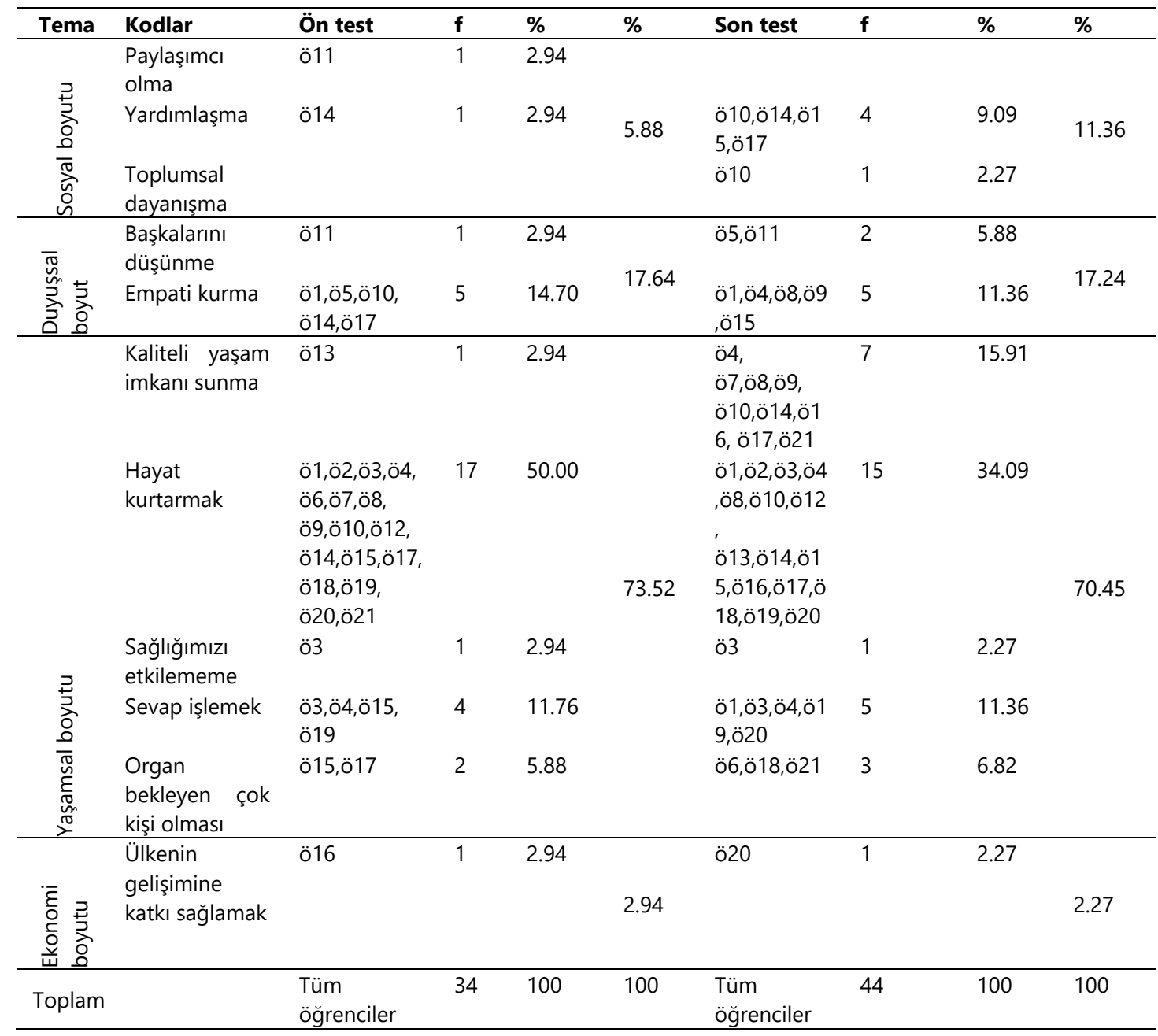


Tablo 4'te organ bağışının yapılması ile ilgili kararların nedenlerine ilişkin öğrencilerin ön ve son formda bulunan açık uçlu sorulara verdiği cevaplar "sosyal boyutu, duyuşsal boyut, yaşamsal boyutu ve ekonomi boyutu" olmak üzere dört tema altında toplanmıştır. Organ bağışının yapılması ile ilgili kararların nedenlerine ilișkin öğrencilerin ön formda yer alan açık uçlu soruya verdiği cevaplar incelendiğinde; $\% 73.52$ 'sinin, son formda ise $\% 70.45^{\prime}$ inin "yaşamsal boyut" ile ilgili ifadelere yer verdiği görülmektedir. Ön ve son formlardan elde edilen bu bulgular doğrultusunda; öğrencilerin insanların yaşamları üzerindeki etkisinden dolayı organ bağışı yapılması gerektiğini belirttiği görülmektedir.

Öğrencilerin organ bağışının yapılıp yapılmamasına ve organ bağışının yapılması ile ilgili kararların nedenlerine ilişkin ön formda verdikleri cevaplardan alıntılar (sırasıyla ö17-ö15 kodlu öğrencilerden) aşağıdaki verilmiştir:
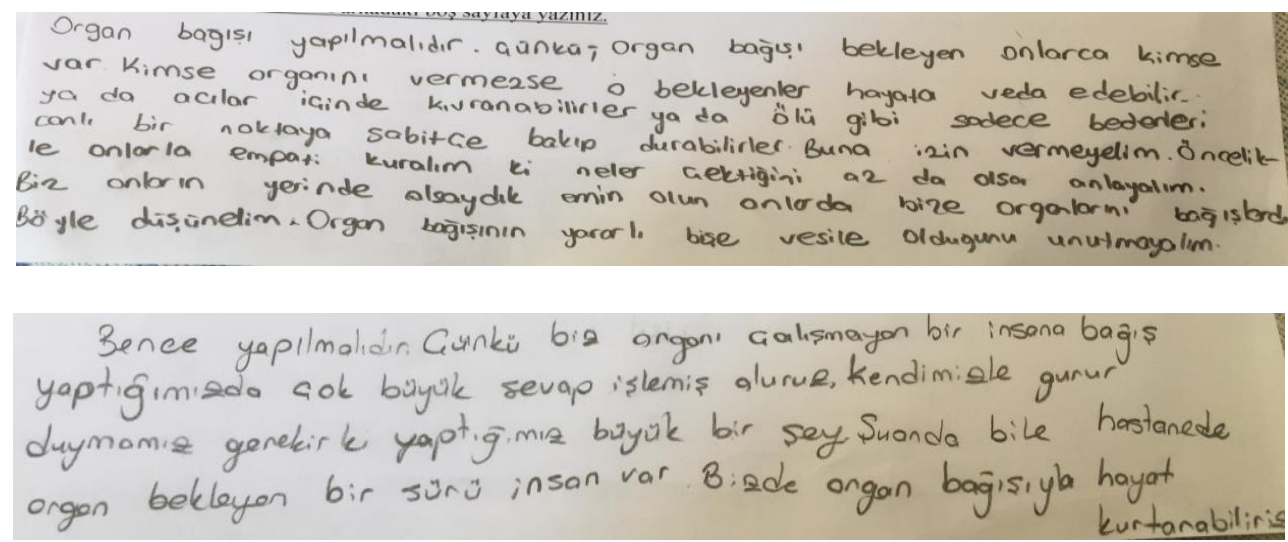

Öğrencilerin organ bağışının yapılıp yapılmamasına ve organ bağışııın yapılması ile ilgili kararların nedenlerine ilişkin son formda verdikleri cevaplardan alıntılar (sırasıyla ö21-ö11 kodlu öğrencilerden) aşağıdaki verilmiştir:
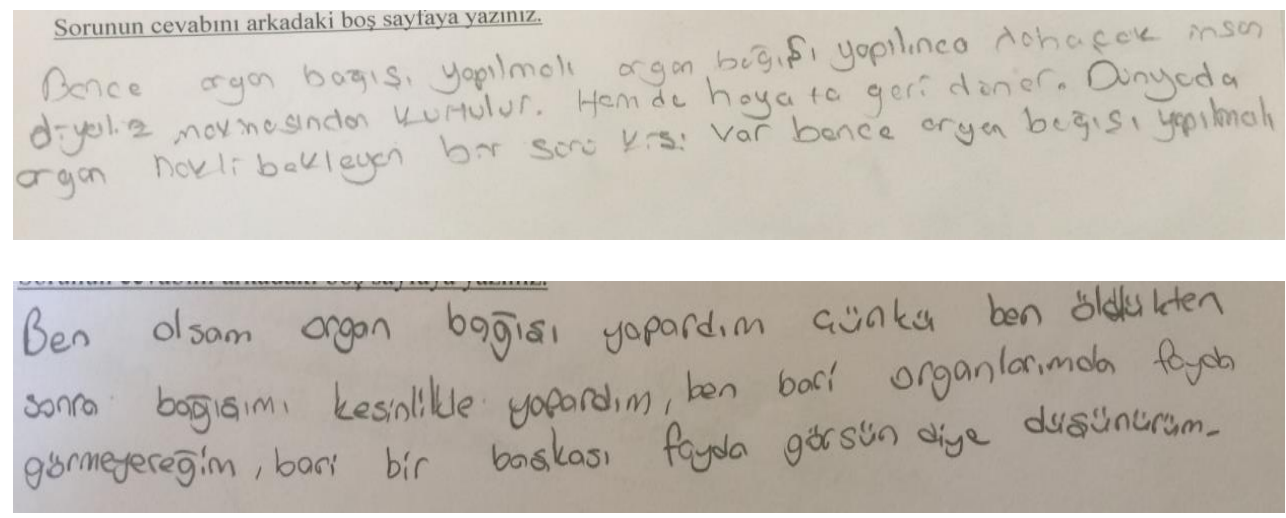

GDO'ya yönelik olan açık uçlu soru formunda yer alan ilk soru ile genetiği değiştirilmiş̧ organizmaların yararlı ya da zararlı olması ile ilgili kararları ve bu kararların nedenlerine yönelik öğrencilerin görüşlerine Tablo 5, Tablo 6 ve Tablo 7'de yer verilmiştir.

Tablo 5'te genetiği değiştirilmiş organizmaların yararlı ya da zararlı olmasına ilişkin ön formda yer alan açık uçlu soruya öğrencilerin verdiği cevaplar incelendiğinde; \%90.48'i genetiği değiştirilmiş organizmaların "zararı" olduğu yönünde kararlarını bildirmiştir. Aynı soruya ilişkin öğrencilerin son formda verdiği cevaplar incelendiğinde ise; \%52.38'i genetiği değiştirilmiş organizmaların "zararı" olduğu yönünde kararlarını belirtmiştir. Ön formlardan elde edilen bu bulgular doğrultusunda; öğrencilerin tamamına yakınının genetiği değiştirilmiş organizmaların zararlı olduğunu, son formlardan elde edilen bu bulgular doğrultusunda ise; yarısının genetiği değiştirilmiş organizmaların zararlı olduğunu belirttikleri tespit edilmiştir. 
Tablo 5

Genetiği Değiştirilmiş Organizmaların Yararlı ya da Zararlı Olmasına Iliş̧kin Öğrencilerin Düşünceleri

\begin{tabular}{|c|c|c|c|c|c|c|c|}
\hline Tema & Kodlar & Ön test & $f$ & $\%$ & Son test & $f$ & $\%$ \\
\hline \multirow{9}{*}{ 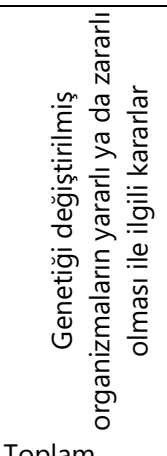 } & Yararlı & ö1 & 1 & 4.76 & ö1,ö4,ö7,ö8,ö9, & 10 & 47.62 \\
\hline & & & & & ö10,ö11,ö12,ö18 & & \\
\hline & & & & & , & & \\
\hline & Zararlı & ӧ3,0̈4,0̈5,ö6,0̈7,ö8 & 19 & 90.48 & ة2,0̈3,ö5,ö6,ö13 & 11 & 52.38 \\
\hline & & ,ö,ö10,ö11,ö12, & & & ö14,ö15,ö16,ö17 & & \\
\hline & & ö13,ö14,ö15,ö16, & & & & & \\
\hline & & ö17,ö18,ö19,ö20 & & & ö19,ö20 & & \\
\hline & Kararsız & ö2,ö21 & 2 & 9.52 & & & \\
\hline & & Tüm öğrenciler & 21 & 100 & Tüm öğrenciler & 21 & 100 \\
\hline
\end{tabular}

Tablo 6'da GDO'ların yararları ile ilgili kararların nedenlerine ilişkin öğrencilerin ön ve son formda bulunan açık uçlu sorulara verdiği cevaplar "toplumsal sorunların çözümüne etkisi, ürününün niteliği üzerine etkisi ve üretim faaliyet ve sürecine etkisi" olmak üzere üç tema altında toplanmıştır. GDO'ların yararları ile ilgili kararların nedenlerine ilişkin öğrencilerin ön formda yer alan açık uçlu soruya verdiği cevaplar incelendiğinde; \%50.00'sinin "ürününün niteliği üzerine etkisi" ve \%50.00'sinin "üretim faaliyet ve sürecine etkisi" ile ilgili ifadelere yer verdiği görülmektedir. Aynı soruya ilişkin öğrencilerin son formda yer alan açık uçlu soruya verdiği cevaplar incelendiğinde ise; \%42.10'unun "toplumsal sorunların çözümüne etkisi" ile ilgili ifadelere vurgu yaptığı belirlenmiştir. Ön formlardan elde edilen bu bulgular doğrultusunda; öğrencilerin GDO'lu ürünlerin kalite ve niteliğinin ve üretim faaliyeti ve sürecinin diğer ürünlere göre daha olumlu olması bakımından GDO'nun yararlı olduğunu belirttiği görülmektedir. Son formlardan elde edilen bu bulgular doğrultusunda; öğrencilerin bu ürünlerin toplumsal sorunların çözümüne katkı sağladığını belirterek yararlı olduğunu dile getirdiği görülmektedir.

\section{Tablo 6}

GDO'ların Yararları ile Ilgili Kararların Nedenlerine ilişkin Öğrencilerin Düşünceleri

\begin{tabular}{|c|c|c|c|c|c|c|c|c|c|}
\hline Tema & Kodlar & Ön test & $f$ & $\%$ & $\%$ & Son test & $f$ & $\%$ & $\%$ \\
\hline \multirow{3}{*}{ 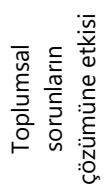 } & $\begin{array}{l}\text { İnsanların ihtiyaçlarını } \\
\text { karşılama }\end{array}$ & & & & & $\begin{array}{l}\text { ö7, } \\
\text { ö8,ö9,ö11 }\end{array}$ & 4 & 21.05 & \multirow{3}{*}{42.10} \\
\hline & Açlığın önüne geçme & & & & & ö9,ö10 & 3 & 15.79 & \\
\hline & $\begin{array}{l}\text { Zararlılar olmadan ürün } \\
\text { üretme }\end{array}$ & & & & & ö12 & 1 & 5.26 & \\
\hline \multirow{3}{*}{ 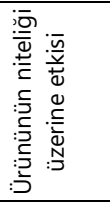 } & Lezzetli olma & & & & \multirow{3}{*}{50.0} & ö21 & 1 & 5.26 & \multirow{3}{*}{26.32} \\
\hline & Verimli ve kaliteli ürün eldesi & ö21 & 1 & 25.0 & & ö1 & 2 & 10.53 & \\
\hline & Dayanıklı ürün & ö1 & 1 & 25.0 & & ö1,ö18 & 2 & 10.53 & \\
\hline \multirow{7}{*}{ 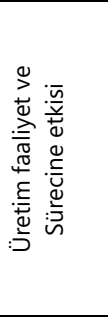 } & Bol ürün eldesi & & & & \multirow{7}{*}{50.0} & ö18 & 1 & 5.26 & \multirow{7}{*}{31.57} \\
\hline & Ucuz ürün eldesi & & & & & ö18 & 1 & 5.26 & \\
\hline & Ürüne kolay ulaşım & & & & & ö4 & 1 & 5.26 & \\
\hline & Kısa sürede ürün eldesi & & & & & ö1,ö21 & 2 & 10.53 & \\
\hline & Tarımsal faaliyetlerin artması & & & & & ö4 & 1 & 5.26 & \\
\hline & Canlılara zarar vermemesi & ö2 & 1 & 25.0 & & & & & \\
\hline & Üreticinin kar sağlaması & ö1 & 1 & 25.0 & & & & & \\
\hline Toplam & & ö2,ö21 & 4 & 100 & 100 & $\begin{array}{l}\text { ö1,ö4,ö7,ö } \\
\text { 8,ö9,ö10,ö } \\
\text { 11,ö12,ö18 } \\
\text {,ö21 }\end{array}$ & 19 & 100 & 100 \\
\hline
\end{tabular}


Tablo 7'de GDO'ların zararları ile ilgili kararların nedenlerine ilişkin öğrencilerin ön ve son formda bulunan açık uçlu sorulara verdiği cevaplar "canlılar üzerindeki etkisi ve ürününün niteliği üzerindeki etkisi" olmak üzere iki tema altında toplanmıştır. GDO'ların zararları ile ilgili kararların nedenlerine ilişkin öğrencilerin ön formda yer alan açık uçlu soruya verdiği cevaplar incelendiğinde; \%71.04'ünün "canlılar üzerindeki etkisi" ile ilgili ifadelere yer verdiği görülmektedir. Aynı soruya ilişkin öğrencilerin son formda yer alan açık uçlu soruya verdiği cevaplar incelendiğinde ise; \%75.00'inin "canlılar üzerindeki etkisi" ile ilgili ifadelere vurgu yaptığı belirlenmiştir. Ön ve son formlardan elde edilen bu bulgular doğrultusunda; öğrencilerin GDO'ların canlılar üzerinde çeşitli zararlı etkileri olduğunu belirttiği görülmektedir.

\section{Tablo 7}

GDO'ların Zararları ile Ilgili Kararların Nedenlerine Ilişkin Öğrencilerin Düşünceleri

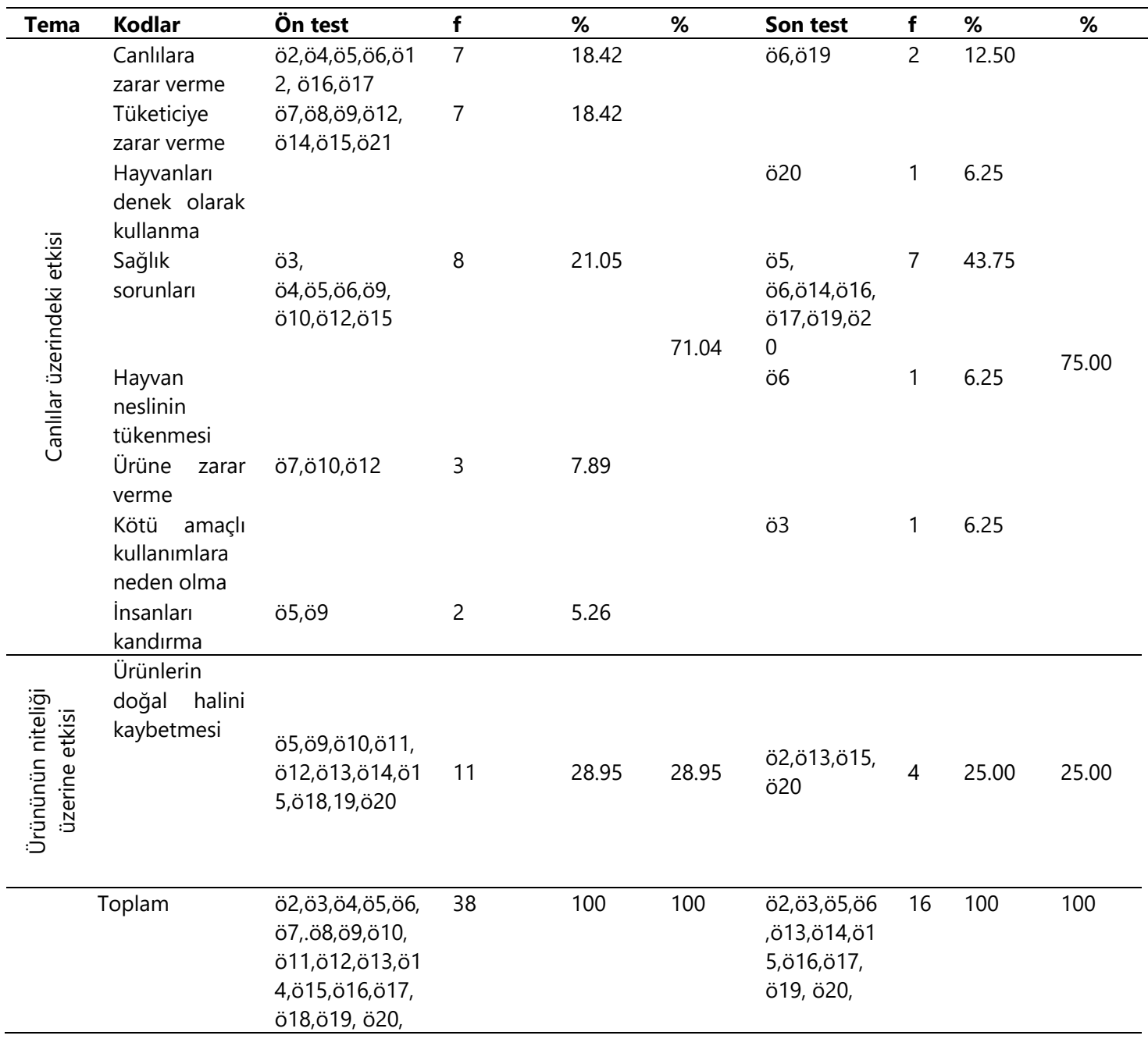

Öğrencilerin genetiği değiştirilmiş organizmaların yararlı ya da zararlı olması ile ilgili kararları ve bu kararların nedenlerine ilişkin ön formda verdikleri cevaplardan alıntılar (sırasıyla ö5-ö7-ö10 kodlu öğrencilerden) aşağıdaki verilmiştir:

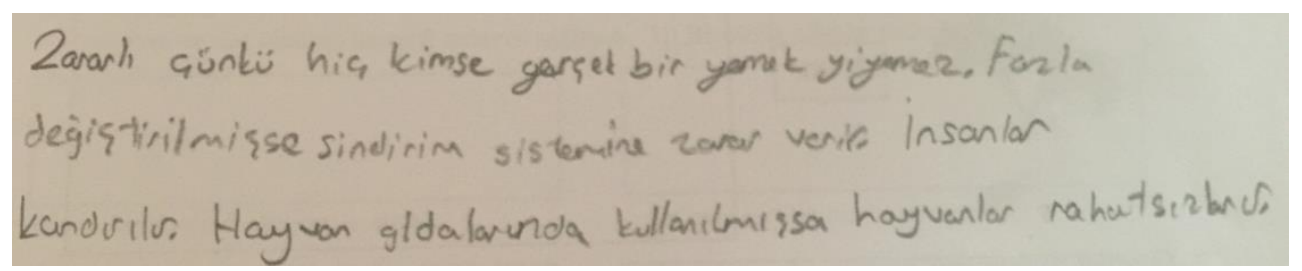




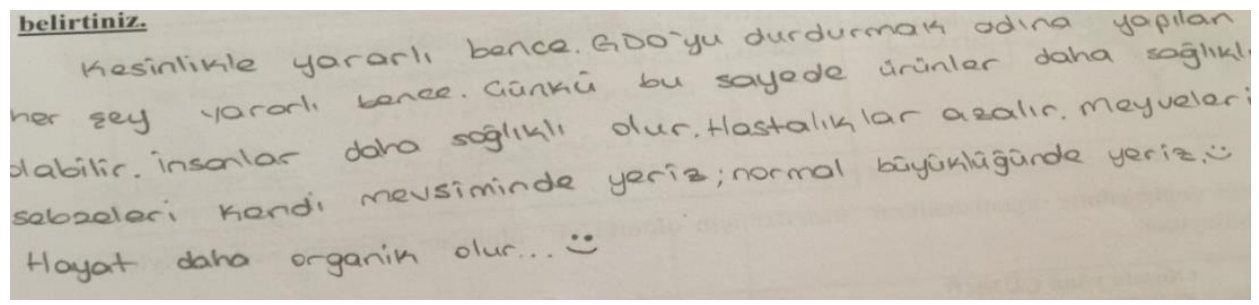

Öğrencilerin genetiği değiştirilmiş organizmaların yararlı ya da zararlı olması ile ilgili kararları ve bu kararların nedenlerine ilişkin son formda verdikleri cevaplardan alıntılar (sırasıyla ö9-ö18 kodlu öğrencilerden) aşağıdaki verilmiştir:
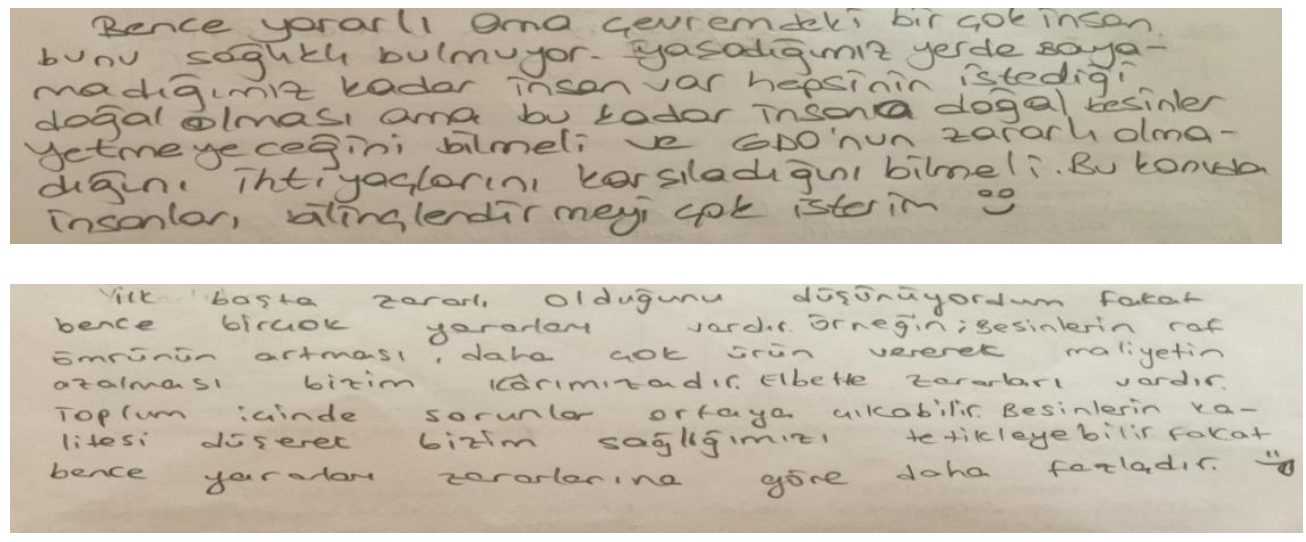

\section{TARTIŞMA, SONUÇ VE ÖNERILER}

Organ bağışının yapılıp yapılmaması sosyobilimsel konusu ile ilgili ziyaret öncesi ve sonrasında uygulanan açık uçlu soru formuna öğrencilerin verdiği cevaplar incelendiğinde; öğrencilerin çoğunluğunun organ bağışının yapılmasına olumlu yönde baktığı tespit edilmiştir. Bu bulgular doğrultusunda öğrencilerin ziyaret öncesinde ve sonrasında bu konu hakkında kararlarının olumlu olduğu ve uygulama öncesinde kararsız olan bir öğrencinin kararının olumlu yönde değişim gösterdiği belirlenmiştir. Bu bağlamda diyaliz merkezinde gerçekleştirilen uygulamanın öğrencilerin düşüncelerini değiştirmediği aksine var olan bilgilerini pekiştirdiğini ve yeni bilgileri etkili bir şekilde öğrenmesine vesile olduğu ifade edilebilir. Çünkü okul dışı öğrenme ortamlarının formal eğitim kapsamında gerçekleşen öğrenmeleri pekiştirici bir etkisi vardır. Bu nedenle okul dışı öğrenme ortamları, öğrencilerin fen konularını anlamlandırıp etkili öğrenmeler gerçekleştirmesinden olumlu katkılar sağlamaktadır (Boaventura ve diğerleri, 2011). Organ bağışının yapılması yönünde kararlarını belirten öğrenciler uygulama öncesi ve sonrasında bu durumun sebebini insan yaşamının değeri ve niteliği üzerindeki etkisine bağlı olarak açıklamıştır. Uygulama öncesi ve sonrasında öğrencilerin bu ifadeye yönelme sıklıkları karşılaştırıldığında; uygulama sonrasında sıklık frekanslarının azalma gösterdiği tespit edilmiştir. Çünkü öğrencilerin bir kısmı uygulama sonrasında daha fazla sıklıkla organ bağışııın toplumsal dayanışma ve yardımlaşmaya katkısına ilişkin açıklamalarda bulunmuştur. Dolayısıyla öğrencilerin kararlarının şekillenmesi bu nedenler çerçevesinde gelişim göstermiştir. Bu durumun nedeni; öğrencilerin diyaliz merkezinde yer alan doktorlardan konunun sosyal açıdan farklı pozitif yönleri hakkında ilk elden ve güvenilir bilgi almış ve diyaliz merkezinde çalışan personelin hasta insanlara karşı olan davranış ve tutumlarını somut bir şekilde görmüş olmaları şeklinde ifade edilebilir. Çünkü okul dışı öğrenme ortamlarl; öğrencilere işin uzmanı olan kişilerden bilgi alma, yerinde görme ve öğrenme, duyularını harekete geçirerek tartışma, sorgulama, gözlem ve araştırma yapmalarını, yaparak-yaşayarak kendi deneyimlerini edinmelerine fırsat tanıyan alanlardır (Ramey-Gassert, 1997; Türkmen, 2010). Bu çalışma kapsamında yer alan öğrenci 
görüşlerine benzer olarak Koçak, Aktaş, Şenol, Kaya ve Bilgin (2010) çalışmalarında; organ bağışında bulunmak isteyen kişi sayısının, kararsız olanlardan; kararsız olanlarında bağışlamak istemeyen bireylerden fazla olduğunu tespit etmiştir. Ayrıca bu kişilerin doktorlara güvenmeme, ailevi ve sosyal gerekçeler ve ticari amaçlı istismarlara maruz kalma gibi nedenlere dayalı olarak organlarını bağışlamak istemedikleri sonucuna ulaşılmıştır.

Genetiği değiştirilmiş organizmaların yararlı ya da zararlı olması sosyobilimsel konusu ile ilgili uygulanan ön ve son açık uçlu soru formlarında yer alan öğrencilerin düşünceleri incelendiğinde; büyük çoğunluğunun uygulama öncesinde GDO'ların zararlı olduğunu, uygulama sonrasında ise; GDO'ların hem yararlı hem de zararlı olduğunu belirttikleri görülmüştür. Bu bulgular doğrultusunda öğrencilerin uygulama öncesinde ve sonrasında bu konu hakkında kararlarının değişim gösterdiği ve uylama öncesinde olumsuz karar veren bazı öğrencilerin kararlarının olumlu yönde değişim gösterdiği belirlenmiştir. Bu uygulama sonucunda yer alan öğrenci düşüncelerinin aksine Demir ve Düzleyen (2012) çalışmalarında 8. sınıf öğrencilerinin GDO'yu yararlı bulmadıklarını belirtmiştir. Aynı şekilde Gülhan (2012) çalışmasında öğrencilerin bu konu hakkında olumlu düşünmediklerini vurgulamıştır. Araştırma merkezinde gerçekleştirilen uygulama sonucunda ortaya çıkan öğrenci düşüncelerine paralel olarak; Massarani ve Moreira (2005) lise öğrencilerinin GDO'lu yiyeceklerin yararlı olabileceğini düşündüklerini tespit etmiştir. Bu araştırma sonucunda öğrencilerin kararlarında gerçekleşen değişimin nedeni; başlangıçta öğrencilerin basit düzeyde, net ve bilimsel olmayan bilgi içeriğine sahip olması ve GDO kavramını somutlaştıramamaları; uygulama sonrasında konunun uzmanı olan genetik mühendislerinden yapılan çalışmalar hakkında daha güvenilir ve ilk elden bilgiler almış, merak ettikleri soruları anında sorabilmelerinin sağlanmış olması ve GDO kavramlarının somut örneklerini görebilmiş olmaları olabilir. Çünkü okul dışı öğrenme ortamları ile değişen, geliştirilen ve zenginleştirilen öğrenme ortamı bireylere sınıf içerisinde sunulması güç olan ilk elden gözlem yapma ve deneyim kazanma fırsatı (Rivkin, 2000; Emmons, 1997) ve fen konularıla ilgili kavram ve nesnelerle etkileşimde bulunma ve merak duygusu uyandırma imkanı sunarak tam ve anlamlı öğrenmelerin gerçekleştirilmesini sağlamaktadır (Ramey-Gassert, 1997). Gülhan (2012) çalışmasında; bilimsel tartışma destekli öğretimin öğrencilerin genetiği değiştirilmiş organizmalarla ilgili görüşlerini değiştirmede etkili olduğunu tespit etmiştir. Bu çalışma kapsamında da okul dışı öğrenme ortamlarının öğrencilerin bu konu ile ilgili kararlarını değiştirmelerinde etkili olduğu vurgulanabilir. GDO'ların yararlı olduğu yönünde kararlarını belirten öğrenciler uygulama öncesinde uygulanan açık uçlu soru formlarında bu durumun sebebini GDO'lu ürünlerin niteliğinin ve üretim faaliyeti ve sürecinin diğer ürünlere göre daha olumlu olmasına bağı olarak açıklamıştır. Uygulama sonrasında gerçekleştirilen açık uçlu soru formlarında ise; öğrencilerin çoğunluğu bu ürünlerin toplumsal sorunların çözümüne katkı sağladığını belirterek yararlı olduğunu dile getirmiştir. GDO'ların zararlı olduğu yönünde kararlarını belirten öğrenciler uygulama öncesinde ve sonrasında bu durumun sebebini GDO'ların canlılar üzerinde çeşitli zararlı etkileri olmasına dayalı olarak açıklamıştır. Elde edilen bu bulgu literatürde var olan bazı çalışmalarda elde edilen sonuçlar ile benzerlik göstermektedir (Demir ve Düzleyen, 2012; Özden ve diğ., 2008; Sönmez, 2011). Bu araştırma kapsamında GDO'lu ürünlerin yarar ve zararlarına ilişkin öne çıkan öğrenci görüşlerinde gerçekleşen frekansın azalma göstermesinin nedeni; bu konulara ilişkin bilmedikleri yeni bilgiler edinmeleri ve konunun farklı yönlerine ilişkin çeşitli bakış açıları kazanmaları olabilir. Çünkü bazı öğrenciler uygulama sonrasında uygulama öncesinde ifade etmediği bazı kısımlara değinmiştir. Literatürde okul dışı öğrenme ortamlarının öğrencilerin farkındalık ve bilgi düzeylerindeki değişimi (Bartley, Mayhew ve Finkelstein, 2009; Fisman, 2005; Pereira ve diğ., 2006; Sanders, 2007; Randler ve diğerleri, 2012) ve öğrenmelerini (Bätz ve diğerleri, 2010; Randler ve diğerleri, 2007; Tosun, 2012) olumlu yönde etkilediğini vurgulayan çalışmalar yer almaktadır.

Sonuç olarak bu araştırmada organ bağışının yapılıp yapılmaması ve genetiği değiştirilmiş organizmaların yararlı ya da zararlı olması sosyobilimsel konuları hakkındaki öğrencilerin kararlarının değişimi ve devamlıı̆ı̆ın nedenleri; alışılagelmişin dışında formal eğitimi 
destekleyecek şekilde öğrenme ortamının sınıfın dışına taşınması şeklinde ifade edilebilir. Buna benzer şekilde Yavuz Topaloğlu ve Balkan Kıyıcı (2017) çalışmalarında sosyobilimsel konulara dayalı okul dışı öğrenme ortamlarında yürütülen etkinliklerin öğrencilerin bir diğer sosyobilimsel konu olan HES hakkında yeni, bilinmeyen ve konunun farklı yönlerini içeren bilgiler öğrenmelerini gerçekleştirdiğini konuyla ilgili bilgi toplama ve bilgi edinmeye katkı sağlayarak herhangi bir konu hakkında karar vermelerinde rol oynadığı sonucuna ulaşmıştır. Bu çalışma kapsamında da öğrenciler uygulama öncesinde olduğu gibi uygulama sonrasında da organ bağışının yapılması gerektiği, GDO konusunda uygulama öncesinde GDO'nun zararlı olduğunu uygulama sonrasında ise yararlı olduğu yönünde de kararlarını ifade etmiştir. Bu çalışmaya ek olarak farklı sosyobilimsel konulara ilişkin öğrencilerin düşüncelerini, sorumluluk bilincini ve bu tür sorunlara ilişkin kaygı düzeylerini belirleyebilmek için daha uzun süreli uygulamaya dayalı çeşitli çalışmalar yürütülebilir. Ayrıca toplumun ilerleyebilmesi için günümüz yetişkinlerinin yanı sıra geleceğin mimarı olan çocukların bu tür sosyobilimsel konular hakkındaki kavram yanılgılarını, farkındalık ve bilgi düzeylerinin araştııılmasına dayalı çalışmalarının sayısı artırılabilir. Araştırma sonuçlarına bağlı olarak küçük yaş grubundaki öğrencilerin sosyobilimsel konular hakkında karar verebilecek veya görüş bildirecek donanıma sahip olmaları sağlanabilir. Bu doğrultuda öğrencilere GDO, organ bağışı ve diğer sosyobilimsel konular ile ilgili çeşitli seminerler ve eğitimler verilebilir, konuyla ilgili bilgi toplayabilecekleri farklı okul dışı öğrenme ortamlarına geziler yapılabilir. Bunlara ek olarak okul dışı öğrenme ortamında yürütülen faaliyetlerin öğrencilerin yaşam, mühendislik ve tasarım becerilerine etkisini sorgulayan çeşitli çalışmalar yapılabilir.

\section{KAYNAKÇA}

Akça, Z. (2016). Müzik eğitimi veren kuruluşların fen eğitiminde kullanılmasının öğrencilerin akademik başarıları ve düşünme becerileri üzerindeki etkisi. (Yayınlanmamış Yüksek Lisans Tezi). Atatürk Üniversitesi, Erzurum.

Akış, M., Katırcı, E., Uludağ, H. Y., Küçükkılıç, B., Gürbüz, T., Türker, Y., ... ve Gül, H. (2008). Süleyman Demirel Üniversitesi personelinin organ-doku bağışı ve nakli hakkındaki bilgi ve tutumları. SDÜ Tıp Fakültesi Dergisi, 15(4), 28-33

Armağan, B.(2015). ilkokul dördüncü sınıf fen öğretiminde okul dışı öğrenme ortamları: Bir eylem araştırması. (Yayınlanmamış Yüksek Lisans Tezi). Dokuz Eylül Üniversitesi, İzmir.

Ary, D., Jacobs, L. C., Sorensen C. \& Razavieh, A. (2010). Introduction to research in education. (8th ed.). Belmont, CA: Wadsworth, Cengage Learning.

Bakioğlu, B. ve Karamustafaoğlu, O. (2014). Okul dışı ortamlarda fen eğitimi: Diyaliz merkezine teknik bir gezi. Turkish Journal of Teacher Education, 3(2), 15-26.

Bartley, J. E., Mayhew, L. M., \& Finkelstein, N. D. (2009, November). Promoting children's understanding and interest in science through informal science education. AIP Conference Proceedings (Vol. 1179, No. 1, s. 93-96). AIP.

Bätz, K., Wittler, S. \& Wilde, M. (2010). Differences between boys and girls in extracurricular learning settings. International Journal of Environmental \& Science Education, 5(1), 51-64.

Bici, İ. (2010). Genetiği değiştirilmiş organizmalar ve biyogüvenlik kavramları ile ilgili öğrencilerin bilgi düzeylerinin ve tutumlarının değerlendirilmesi (Yayınlanmamış yüksek lisans tezi). Gazi Üniversitesi, Ankara.

Bilen, K. ve Özel, M. (2012). Üstün yetenekli öğrencilerin biyoteknolojiye yönelik bilgileri ve tutumları. NEFEFMED,6(2), 135-152.

Boaventura, D., Faria C., Chagas I. \& Galvão C. 2011. Promoting science outdoor activities for elementary school children: Contributions from a research laboratory. International Journal of Science Education, 35(5), 796-814.doi.org/10.1080/09500693.2011.583292

Bölükbaş, N., Eyüpoğlu, A., \& Kurt, P. (2004). Organ bağışı hakkında üniversite öğrencilerinin düşünceleri. Journal of Experimental and Clinical Medicine, 21(2), 73-77.

Creswell, J.W. (2008). Educational research planning, conducting, and evaluating qualitative research. (3rd Ed.). NJ: Pearson Education.

Çetin, G., Turgut, M. ve Kaçar, H. (2014). High school students' knowledge and attitudes of organ donation and organ transplantation. Procedia-Social and Behavioral Sciences, 116, 2813-2818. doi.org/10.1016/j.sbspro.2014.01.662 
Demir, B. ve Düzleyen, E. (27-30 Haziran 2012). İlköğretim 8. Sınıf Öğrencilerinin GDO Bilgi Düzeylerinin İncelenmesi. X. Ulusal Fen Bilimleri ve Matematik Eğitimi Kongresi, 27-30 Haziran 2012, Niğde: Niğde Üniversitesi Eğitim Fakültesi.

Demirci, A. (2008). Perceptions and attitudes of geography teachers to biotechnology: A study focusing on genetically modified (GM) foods. African Jornal Of Biotechnology, 7(23), 4321-4327.

Doğan, P., Toprak, D., Sunal, N. ve Doğan, İ. (2012). Knowledge, attitude and behaviors of university students on organ transplantation. Turkey. Smyrna Tip Dergisi, 2(1), 16-25

Driver, R., Newton, P. \& Osborne, J. (2000). Establishing the norms of scientific argumentation in classrooms. Science Education, 84(3), 287-312.

Emmons, K. M. (1997). Perceptions of the environment while exploring the outdoors: A case study in Belize. Environmental Education Research, 3(3), 327-344. doi.org/10.1080/1350462970030306

Ergin, I., Gürsoy, Ş. T., Öcek, Z. A., \& Çiçeklioğlu, M. (2008). Sağlık meslek yüksekokulu öğrencilerinin genetiği değiştirilmiş organizmalara dair bilgi tutum ve davranışları. TAF Preventive Medicine Bulletin, 7(6), 503-508.

Fisman, L. (2005). The effects of local learning on environmental awareness in children: An emprirical Investigation. The Journal of Enviromental Education, 36(3), 39-50. doi.org/10.3200/JOEE.36.3.39-50

Gülhan, F. (2012). Sosyo-bilimsel konularda bilimsel tartışmanın 8. sınıf öğrencilerinin fen okuryazarlığı, bilimsel tartışmaya eğilim, karar verme becerileri ve bilim-toplum sorunlarına duyarlılılarına etkisinin araştırılması. (Yayınlanmamış Yüksek Lisans Tezi). Marmara Üniversitesi, İstanbul.

Kılınç, A., Kartal, T., Eroğlu, B., Demiral, Ü., Afacan, Ö., Polat, D., ... \& Görgülü, Ö. (2013). Preservice science teachers' efficacy regarding a socioscientific issue: A belief system approach. Research in Science Education, 43(6), 2455-2475.

Koçak, A., Aktaş E. Ö., Şenol E., Kaya A. ve Bilgin U. E. (2010). Ege Üniversitesi Tıp Fakültesi öğrencilerinin organ nakli ve bağışı hakkındaki bilgi düzeyi, Ege Tıp Dergisi, 49(3), 153-160.

Kolstø, S. D., Bungum, B., Arnesen, E., Isnes, A., Kristensen, T., ... \& Ulvik, M. (2006). Science students' critical examination of scientific Information related to SSI. Science Education, 90(4), 632-655. doi.org/10.1002/sce.20133.

Massarani, L. \& Moreıra, I. C. (2005). Attitudes towards genetics: A case study among Brazilian high school students. Public Understanding of Science, 14, 201-212.doi.org/10.1177/0963662505050992

Melber, L. H. \& Abraham, L. M. (1999). Beyond the classroom: Linking with informal education. Science Activities, 36(1), 3-4.doi.org/10.1080/00368129909601027

Miles, M. B. \& Huberman, M. A. (1994). An expanded sourcebook qualitative data analysis. London: Sage Publication.

Nuangchalerm, P. (2010). Engaging students to perceive nature of science through socioscientific Issuesbased instruction. European Journal of Social Sciences, 13(1), 34-37

Özdemir, O., Güneş, M.H. ve Demir, S. (2010). Üniversite öğrencilerinin genetiği değiştirilmiş organizmalara (GDO'lara) yönelik bilgi düzeyleri-tutumları ve sürdürülebilir tüketim eğitimi açısından değerlendirilmesi. Ondokuz Mayıs Üniversitesi Eğitim Fakültesi Dergisi, 29(1), 53-68.

Özden, M., Usak, M., Prokop, P., Türkoglu, A. ve Bahar, M. (2008). Student teachers' knowledge of and attitudes toward chemical hormone usage in biotechnology. African Journal of Biotechnology, 7(21), 3892-3899.

Patton, Q. M. (2014). Nitel araştırma ve değerlendirme yöntemleri. (M. Bütün, ve S. B. Demir, Çev.). Ankara: PegemA.

Pereira, R., Pinho, R., Lopes, L., Antunes, S.C., Abrantes, N. \& Gonçalves, F. (2006). Helping teachers to use urban natural areas for science teaching and environmental education. Fresenius Environmental Bulletin, 15(11), 1467-1473.

Ramey-Gassert, L. (1997). Learning science beyond the classroom. The Elementary School Journal, 4, 433450.

Randler, C., Baumgärtner, S., Eisele, H. \& Kienzle, W. (2007). Learning at workstations in the zoo: A controlled evaluation of cognitive and affective outcomes. Visitor Studies, 10(2), 205-216. doi.org/10.1080/10645570701585343

Randler, C., Kummer, B. \& Wilhelm, C. (2012). Adolescent learning in the zoo: Embedding a non-formal learning environment to teach formal aspects of vertebrate biology. Journal of Science Education and Technology, 21(3), 384-391. doi.org/10.1007/s10956-011-9331-2

Ratcliffe, M., \& Grace, M. (2003). Science education for citizenship. Teaching socio-scientific issues. Maidenhead: Open University Press.

Rivkin, M. S. (2000). Outdoor experiences for young children. Erişim tarihi: 07.08.2017, https://www.ericdigests.org/2001-3/children.htm. 
Sadler, T. (2004). Informal reasoning regarding SSI: A critical review of research. Journal of Research in Science Teaching, 41(5), 513-536.doi.org/10.1002/tea.20009

Sadler, T. D. \& Zeidler, D. L. (2004). The Morality of socioscientific Issues construal and resolution of genetic engineering dilemmas. Science Education, 88(1), 4-27.doi.org/10.1002/sce.10101

Sadler, T. D. \& Zeidler, D. L. (2005). Patterns of Informal reasoning in the context of socioscientific decision making. Journal of Research in Science Teaching, 42(1), 112-138. doi.org/10.1002/tea.20042

Sanders, D. L. (2007). Making public the private life of plants: The contribution of informal learning environments. International Journal of Science Education, 29(10), 1209-1228. doi.org/10.1080/09500690600951549

Saylan, A. (2014). Relationships among pre-service science teachers' epıstemological belıefs, knowledge level and trustworthiness on information sources: Clımate change, nuclear energy, and organ donation and transplantatıon (Unpublished Master's Thesis) Mıddle East Technıcal Unıversıty, Ankara.

Sontay, G., Tutar, M. ve Karamustafaoğlu, O. (2016). "Okul Dışı Öğrenme Ortamları ile Fen Öğretimi" Hakkında Öğrenci Görüşleri: Planetaryum Gezisi, Informal Ortamlarda Araştırmalar Dergisi, 1(1), 1 24.

Sönmez, A. (2011). Fen ve teknoloji öğretmen adaylarının Gdo'lu besinler hakkındaki bilgileri, risk algıları, tutumları ve böyle bir konunun öğretimine yönelik öz yeterlilikleri (Yayınlanmamış Yüksek Lisans Tezi). Ahi Evran Üniversitesi, Kırşehir.

Şahin, F. ve Yazgan, B. S. (2013). Araştırmaya dayalı sınıf dışı laboratuar etkinliklerinin öğrencilerin akademik başarılarına etkisi. Sakarya University Journal of Education, 3(3), 107-122.

Tosun, F. (2012). Ilköğretim canlılar dünyasını gezelim tanıyalım ünitesinin anlaşılmasında gezi gözlem ve düz anlatım yöntemlerinin karşılaştırılması. (Yayınlanmamış Yüksek Lisans Tezi). Ondokuz Mayıs Üniversitesi, Samsun.

Türkmen, H. (2010). İnformal (sınıf-dışı) fen bilgisi eğitimine tarihsel bakış ve eğitimimize entegrasyonu. Çukurova Üniversitesi Eğitim Fakültesi Dergisi, 3(39), 46-59.

Yanmaz, D. (2017). Doğa Tarihi Müzesinde Rehber Hazırlama ve Çalışma Yaprakları ile Öğretimin Öğrencilerin Akademik Başarı ve Fen Öğrenimine Yönelik Motivasyonları Üzerine Etkisi. (Yayınlanmamış Yüksek Lisans Tezi). Muğla Sıtkı Koçman Üniversitesi, Muğla.

Yavuz Topaloğlu, M. ve Balkan Kıyıcl, F. (2017). Ortaokul öğrencilerin hidroelektrik santrali hakkındaki görüşleri. Journal of Kirsehir Education Faculty, 18(1), 159-179.

Yıldırım, A. ve Şimşek, H. (2011). Sosyal bilimlerde nitel araştırma yöntemleri. (8.Baskı). Ankara: Seçkin Yayıncılık.

Zeidler, D. L. \& Keefer, M. (2003). The Role of moral reasoning and the status of SSI in science education: Philosophical, psychological and pedagogical considerations. D. L. Zeidler (Ed.). The Role of Moral Reasoning and Discourse on SSI in Science Education. (pp7-38). Dordrecht the Netherlands: Kluwer Academic Publishers.

Zeidler, D. L. \& Sadler, T. D. (2008). Social and ethical issues in science education: A prelude to action. Science \& Education, 17(8), 799-803. doi.org/10.1007/s11191-007-9130-61 


\section{The Effect of Activities Conducted in out-of-School Learning Environments on Students' Opinions about Socio-scientific Issues: Organ Donation and Genetically Modified Organisms}

\author{
Dr.Melike Yavuz Topaloğlu \\ Minister of National Education -Turkey \\ meykeyavuz@hotmail.com
}

\author{
Assoc.Prof.Dr. Fatime Balkan Kıyıcı \\ Sakarya University-Turkey \\ fbalkan@sakarya.edu.tr
}

\begin{abstract}
This study aims to determine the opinions of the seventh grade students the activities related to organ donation and GMOs within out-of-school learning environments. This descriptive study was conducted with twenty-one seventh grade students attending a middle school during 2014-2015 academic year.During the research process, two field trips were organized to dialysis center and TUBITAK Marmara research center. Research data was obtained with open ended questionnaire were applied to students before and after the field trip. The data were analyzed with content analysis method.The study concluded that most students considered the GMOs as harmful as they caused a variety of health problems and other issues in living beings before and after their implementation in the TUBITAK Marmara research center, and the products lost their natural status. Moreover, it was observed that the number of the students who considered the GMOs as beneficial increased dramatically after the implementation. The students had positive opinions about organ donation before and after their visits to the dialysis center for the vital dimensions (e.g. provision of a quality living, saving lives and a large number of people waiting for organs).
\end{abstract}

Keywords:Genetically modified organisms, organ donation, out-of-school learning environments, socio-scientific ıssues, students'opinions

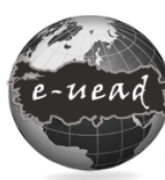

E-International Journal of Educational Research, Vol: 9, No: 1, 2018, pp. 36-50

DOI: 10.19160/ijer.350189

\section{Suggested Citation:}

Yavuz Topaloğlu, M. \&. Balkan Kıyıcı, F. (2018). The Effect of Activities Conducted in Out-Of-School Learning Environments on Students' Opinions About Socio-scientific Issues: Organ Donation and Genetically Modified Organisms, E-International Journal of Educational Research, Vol: 9, No: 1, 2018, pp. 36-50, DOI: 10.19160/ijer.350189 


\section{EXTENDED ABSTRACT}

Problem: Organ donation and genetically modified organisms (GMOs) are socio-scientific issues because of some controversies. For this reason, it is important that all individuals have the knowledge and awareness of socio-scientific issues to express their own opinions in society. In these circumstances especially, children are more important than adults because of composing the future of societies. When the studies in the literature was examined, it can be seen that as most of the individuals have inadequate and wrong information about these topics, they need to be trained about these topics to decide. Thus, besides classroom activities, out-of-school learning environments can also be used as a education tool to perceive and interpret socioscientific issues correctly and effectively. The opportunity to examine controversial social problems, which cannot be agreed upon in daily life, in their own natural environment is being provided to the students in the out-of-school learning environments. Educational activities conducted in this kind of learning environments help the students learn with their own senses and experiences, learn many socio-scientific topics at the same time with interaction in this way they construct their own knowledge about the subject. In this sense this study can be filled with the lack in the literature of discussing both socio-scientific issues and out-of-school learning environments together and defining the middle students 'opinions about these socio-scientific issues.

Purpose: This study aims to determine the opinions of the seventhgrade students on the activities related to organ donation and GMOs within out-of-school learning environments.

Method: This is a descriptive study revealing the opinions of the students on two socio-sceintific issues. The study was conducted with twenty-one seventh grade students attending a middle school during 2014-2015 academic year. In this study, there were some required criteria participants should have been being a $7^{\text {th }}$ grade student, available for out-of-school activities and aware of socio-scientific issues. Therefore, purposive sampling method was used. During the research process, two field trips were organized to dialysis center and TUBITAK Marmara research center in two different days. Research data was obtained with open ended questionnaire about organ donation and GMO developed researcher were applied to students before and after the field trip. The data gathered from open ended questionnaire were analyzed with content analysis method.

Findings:The open-ended question in the preliminary form that was related to decisions regarding organ donation indicated that $73.52 \%$ of the students responded using expressions related to the 'vital dimension,' while this rate was $70.45 \%$ in the final form. A review of the students' responses to the open-ended question, in the preliminary form, related to the genetically modified organisms' (GMOs) being beneficial or harmful showed that $90.48 \%$ of the students believed that the GMOs were harmful. Their responses to the same question in the final form showed that $52.38 \%$ of the students deemed the GMOs as harmful. The students also responded to an open-ended question in the preliminary form about the reasons for their decisions on the benefits of GMOs, and $50 \%$ of the students mentioned the 'effect on the quality of the product' and 50\% mentioned their 'effect on the manufacturing operations and process.' They responded to the same question in the final form also, and $42.10 \%$ of the students emphasized the 'effect on the solution of social problems.' The responses to the openended question in the preliminary form about the decisions related to the harms of GMOs revealed that $71.04 \%$ of the students mentioned the 'effect on the living beings.' The responses to the same question in the final form revealed that $75 \%$ of the students emphasized the 'effects on the living beings. 
Discussion \& Conclusion:The study concluded that most students considered the GMOs as harmful as they caused a variety of health problems and other issues in living beings before and after their implementation in the TUBITAK Marmara research center, and the products lost their natural status. Moreover, it was observed that the number of the students who considered the GMOs as beneficial increased dramatically after the implementation due to many reasons including the solution of social problems such as meeting people's needs and preventing hunger, manufacturing quality products that were productive and durable, and short production process. The students had positive opinions about organ donation before and after their visits to the dialysis center for the vital dimensions (e.g. provision of a quality living, saving lives and many people waiting for organs). Moving the learning environment outside the classroom to support the formal education altered and maintained the students' opinions and decisions related to these two socio-scientific issues. These environments influence the students' decisions and formation of opinions considering the rigidity of concepts, reception of information from the first day, testing the accuracy of their pre-existing information about these issues, and learning about the unknown and new sides of this matter. 